\title{
The Impact of Corporate Social Responsibility Disclosure and Accounting Comparability on Earnings Persistence
}

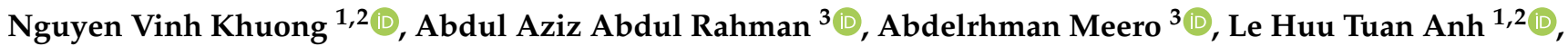 \\ Nguyen Thanh Liem ${ }^{2,4, * \mathbb{C}}$, Cao Thi Mien Thuy ${ }^{2,4}$ (1) and Huynh Thi Ngoc Ly ${ }^{2,5}$ \\ 1 Faculty of Accounting and Auditing, University of Economics and Law, Ho Chi Minh City 700000, Vietnam; \\ khuongnv@uel.edu.vn (N.V.K.); anhlht18409c@st.uel.edu.vn (L.H.T.A.) \\ 2 Vietnam National University, Ho Chi Minh City 700000, Vietnam; thuyctm17704@sdh.uel.edu.vn (C.T.M.T.); \\ lyhtn@uel.edu.vn (H.T.N.L.) \\ 3 College of Business Administration, Kingdom University, Riffa 40434, Bahrain; \\ a.abdulrahman@ku.edu.bh (A.A.A.R.); ar.meero@ku.edu.bh (A.M.) \\ 4 Faculty of Finance and Banking, University of Economics and Law, Ho Chi Minh City 700000, Vietnam \\ 5 Institute for Development and Research in Banking Technology, University of Economics and Law, \\ Ho Chi Minh City 700000, Vietnam \\ * Correspondence: liemnt@uel.edu.vn
}

check for

updates

Citation: Khuong, N.V.; Rahman,

A.A.A.; Meero, A.; Anh, L.H.T.; Liem, N.T.; Thuy, C.T.M.; Ly, H.T.N. The Impact of Corporate Social Responsibility Disclosure and Accounting Comparability on Earnings Persistence. Sustainability 2022, 14, 2752. https://doi.org/ $10.3390 /$ su14052752

\section{Academic Editor:}

Mohammad Nurunnabi

Received: 21 January 2022

Accepted: 11 February 2022

Published: 26 February 2022

Publisher's Note: MDPI stays neutral with regard to jurisdictional claims in published maps and institutional affiliations.

Copyright: (c) 2022 by the authors. Licensee MDPI, Basel, Switzerland. This article is an open access article distributed under the terms and conditions of the Creative Commons Attribution (CC BY) license (https:/ / creativecommons.org/licenses/by/ $4.0 /)$.

\begin{abstract}
The study aims to provide empirical evidence on the impact of corporate social responsibility (CSR) and accounting comparability (AC) on earnings persistence (EP) in listed firms on the Vietnamese stock market. Data were collected from 76 companies that have disclosure financial statements, annual reports, and CSR of companies and listed firms on the Vietnamese stock market in the period from 2014 to 2017. The study used the Generalized Method of Moments (GMM) regression method to evaluate the correlation. We believe that CSR and AC have a positive impact on EP. The study helps to contribute to a review of previous studies on the relationship between CSR disclosure, $\mathrm{AC}$ and EP in developing countries. The study points out some policy implications for regulators and firms on transparency in an information disclosure to increase AC and CSR on the basis of maintaining EP.
\end{abstract}

Keywords: corporate social responsibility; accounting comparability; earnings persistence

\section{Introduction}

CSR has garnered increased attention from publicly traded companies, government agencies, and researchers [1]. Disclosure CSR is the dissemination of financial and nonfinancial information about the environment, the community in which the business operates, and the society to which the firm contributes. Carroll [2] stated that CSR is concerned with society's economic, legal, ethical, and political expectations at any particular period. According to Freeman [3], CSR is concerned with the company's stakeholders, those who directly or indirectly influence or are impacted by the company's actions. Specifically, CSR reports on the economic, environmental, and social concerns affecting the business are compiled and released annually in the company's annual reports [4,5]. CSR has become a critical factor in corporate decision-making, and many organizations now plan, perform, and manage their CSR activities in order to be able to publicly report them [6,7]. Numerous CSR studies have been conducted on industrialized economies like the United States, the United Kingdom, and other European countries [1,8-10]. In industrialized nations, companies have built and altered CSR concepts, norms, and frameworks over a reasonably lengthy period. According to academics, mature economies pay more attention to CSR than emerging economies do [11,12]. Countries at varying levels of economic and social development have varying effects on CSR awareness and practice [12,13]. Additionally, different cultural and traditional conventions have a varying effect on how CSR is perceived [14]. Although affluent countries engage in a large amount of CSR [1,12], numerous 
research studies on CSR and EP in developing countries, particularly in Indonesia and China, indicate a favorable association between CSR and EP $[15,16]$. However, little is known about how CSR is seen and implemented in developing countries, particularly in Vietnam, which has experienced rapid economic expansion in recent decades [17-19].

Vietnam is a prime example of a developing country undergoing rapid economic expansion while also confronting social difficulties spurred by rising corporate activity. However, there is currently a shortage of studies on CSR in the Vietnamese context, even though the country's diverse political, economic, social, and cultural circumstances give Vietnam an ideal location for popular CSR ideas in the present. These contextual elements, which include governmental institutions and business models, have affected the development of the CSR framework [17]. By finishing research on CSR in the food retail business, and by combining the perspectives of various key stakeholders and consumers, this study identifies eight key themes that govern CSR activities in the food retail industry: the implementation of activities that demonstrate fairness and equality, ensure food quality and safety, promote information transparency, create favorable procurement conditions, protect employee rights, and promote environmental protection and charitable activities [19]. Relatively few studies have been conducted in the Vietnamese market [20]. In particular, there has been no study on the link between CSR and EP in Vietnam or between CSR and AC.

Our study makes a variety of contributions to the existing literature. Firstly, this is the first paper that explores the impact of $\mathrm{AC}$ on $\mathrm{EP}$ in an emerging market such as Vietnam. Besides, our findings are robust, and through many robustness tests, we have also changed the indicators representing CSR and AC. Thirdly, in the Vietnamese context, few research measures on CSR activities based on the 2016 GRI general standards have been implemented to cover all aspects of CSR. On the other hand, this paper provides helpful empirical evidence for policymakers in developing countries to issue regulations and policies on CSR as well as enhance AC.

The following portions of the study are organized as follows: The Section 2 introduces the background theory and develops the research hypothesis; the Section 3 details the research methods; Section 4 summarizes and analyzes research results; and Section 5 addresses the study's conclusions and implications for firms, as well as some of the subjects covered.

\section{Literature Review and Hypothesis Development}

According to stakeholder theory, CSR efforts assist businesses in efficiently managing relationships with their stakeholders by enabling them to build, develop, and sustain connections with critical resources [21,22]. Companies with superior CSR operations communicate with their stakeholders more frequently [23]. The effect of CSR disclosure on EP is based on the stakeholder hypothesis which holds that an organization's longevity is highly influenced by support groups associated with its headquarters [24]. To foster stakeholder connections and to safeguard stakeholder interests, firms frequently publish the quality of earnings as reflected earnings smoothing $[15,25]$. As a result, positive connections among stakeholders may help businesses. On the other hand, poor stakeholder interactions expose businesses to additional risks and increase their susceptibility to corporate crisis [26,27]. As a result, developing positive connections with stakeholders may help a business operate better [21,28-30].

According to the signaling theory, stakeholders utilize information to make decisions that benefit them [31,32]. A company's good CSR disclosure will communicate and project a more positive image to the public than a company's poor CSR disclosure [33-35]. Orlitzky, Schmidt [36], and Peloza [37] have shown that CSR disclosure can help mitigate company risk. Businesses can post extremely socially responsible information as a result of developing stronger ties with consumers and suppliers as well as by establishing a brand and reputation for high-quality products and services. Additionally, being attentive to social and environmental changes may help organizations enhance performance, reduce chances 
for income management, and so retain the stability of high-quality financial statements while increasing EP $[16,38]$.

According to legal theory, firms always exist within certain culture, institutions, and laws [39]. As a result, businesses are under societal and political pressure to demonstrate their legitimacy by actions that benefit society and enhance the environment in which they operate [40]. CSR enables businesses to obtain social credibility [41]. However, businesses with questionable sustainability practices choose to make low-quality sustainability claims in order to obscure their genuine activities while maintaining their validity [35]. On a more positive note, increasing a company's legitimacy enables it to fulfill the promises required by stakeholders, resulting in decreased investment risks. The organization tries to increase employee pleasure while also gaining societal recognition and ensuring long-term viability [42]. Legitimacy confers a "permit to operate", a critical and minimum essential component of a business's reputation and hence a valuable intangible asset $[43,44]$. When a business exceeds the legal minimum, further reputational benefits can be realized, for example, by recruiting more qualified staff and loyal consumers $[45,46]$. Thus, authorized actions aid the business in improving its performance [38,41,47-49]. In summary, we anticipate that social responsibility claims aids in increasing EP, and so the following study hypothesis is stated:

\section{Hypothesis 1. CSR disclosure has a positive association with earnings persistence.}

Transactions have been recorded, summarized, and presented in financial statements to provide users with accounting information. Users of financial statements may only utilize, analyze, and compare the accounting information included in financial statements if the companies' accounting systems are comparable, demonstrating that comparability can be defined as the degree of similarity between firms' accounting systems [50]. In other words, comparability refers to the extent to which identical transactions are treated similarly and dissimilar ones differently. According to the Financial Accounting Standards Board (FASB) [51], the major purpose for the development of accounting standards is comparability. Accounting standards standardize the selection and implementation of accounting procedures for economically comparable businesses and minimize industry-specific norms that encourage comparability. Srivastava [52] states that changes in accounting quality metrics such as the relevance of value and earnings volatility are mostly determined by economic fundamentals rather than accounting changes, implying a major absence of fundamentals for earnings characteristics. As a result, the comparability of accounting policy is primarily decided, particularly during short time spans. That is to say, comparability is mostly determined by external, environmental factors. To bolster this argument, the study posits that managers' management reporting is mostly undertaken in the short term [53]. This assumption is also inherent in the comparability metric, as quarterly data from a number of prior years are utilized to determine comparability in the current year [50].

According to signal theory, when enterprises earn a high profit, grow their revenue, and maintain a positive image, they send a signal to investors, organizations, and users who wish to utilize financial data to make sound decisions [54]. Financial statements of firms within a country or area must follow a common accounting policy regime that ensures the information contained in the financial statements is easily readable by users while also assuring comparability. Numerous recent research has explored the impact of comparability on financial statements; research has emphasized the benefits of comparability, such as enhanced analyst follow-up [50], less credit risk [55], and a higher degree of mergers and acquisitions in foreign-owned firms [56]. Discretionary accruals linked with inadequate governance are positively correlated with future performance, which they interpret as evidence that discretionary accruals fulfill future performance expectations [57,58]. Managers can get fresh information from their colleagues' financial records, update their preliminary data, and adjust their activities accordingly. Comparability, according to research, minimizes the cost of data gathering and processing, hence boosting the amount and quality of 
data $[50,55,56,59]$. Comparability broadens the pool of knowledge available to managers, facilitating data aggregation and minimizing judgmental ambiguity. As a result, managers should have a better understanding of the industry and its general environment. This will enable management to assess a company's comparable performance and to comprehend and forecast economic developments and their influence on the business. We anticipate that managers increase their expertise and familiarity with their company environment in order to submit higher-quality accruals [59-62]. In summary, we anticipate that discretionary accruals reported by managers with greater knowledge will be of higher quality and help sustain profitability. The following is the second hypothesis:

Hypothesis 2. Accounting comparability has a positive association with earnings persistence.

\section{Methodology}

\subsection{Data}

Between 2014 and 2017, a sample of listed enterprises on Vietnam's stock market was gathered. Financial, banking, and securities businesses of a transactional orientation were removed from the research sample because economic conditions change, and business lines evolve. We excluded the firms mentioned above to obtain data on comparability and the amount of social responsibility disclosure as well as to assure the study sample's trustworthiness. As a result, we selected a study sample of 76 businesses and extracted data from financial statements, annual reports, and CSR reports of enterprises listed on the Vietnamese stock market.

Vietnamese' capital market structure includes nine primary industries: Basic Materials, Consumer Cyclicals, Consumer Non-Cyclicals, Energy, Healthcare, Industrials, Technology, Utilities, Financial sector. Excluded banking and finance industry, our sample represents nearly $60 \%$ market capitalization value, and chosen companies are spread across the remaining industries.

\subsection{Estimation Method}

We analyzed the data using the GMM technique [63]. GMM estimation is used to account for two fundamental issues: heterogeneity and endogeneity [64]. To ascertain the amount of delays, we used the Hansen over-determining constraint test [65]. Then, we employed another measure of comparability and analyze the outcomes between the two measures to strengthen the study model's robustness.

\subsection{Model}

The study model is based on the research of Chen and Gong [59], Lassaad and Khamoussi [66]; The following model is proposed:

$$
\begin{aligned}
\text { PERSITENCE } E_{i t}= & \delta_{0}+\delta_{1} \text { COMPACC }_{i t-1}+\delta_{2} \mathrm{CSR}_{i t}+\delta_{3} \operatorname{SIZE}_{i t}+\delta_{4} \mathrm{CASH}_{i t} \\
& +\delta_{5} D I V Y_{i t}+\delta_{6} A G E_{i t}+\delta_{7} D E B T_{i t}+\varepsilon_{i t}
\end{aligned}
$$

In there,

The value $i$ runs from 1 to 76 (76 companies respectively);

The value $t$ runs from 1 to 4 (4 years respectively, from 2014 to 2017);

Dependent variable

PERSISTENCE: a metric for EP that is calculated using financial statement components and may be found throughout the financial statement [61,67]. After doing an OLS regression on Equation $(*)$, obtaining the coefficient $\beta_{1}$, which symbolizes the income's stability:

$$
\text { Earnings }_{i, t+1}=\alpha+\beta_{1} * \text { Earnings }_{i, t}+\varepsilon(*)
$$

where Earnings $s_{i, t+1}$ and Earnings $s_{i, t}$ are the earnings per share (EPS) of firm $i$ for years $t+1$ and $t$, respectively, as computed using the year $\mathrm{t}$ stock price.

Independent variables 
COMPACCT: Comparability is utilized by empirically quantify the AC of firm i in year $t$ using the technique of De Franco, Kothari [50]. To begin, the preceding 16 quarters' data are utilized to estimate the following equation, in which earnings is defined as the ratio of net income to the market value of equity at the start of the period. The return in Equation (1) refers to the stock's quarterly return.

$$
\text { Earnings }_{i t}=\alpha_{\mathrm{i}}+\beta_{\mathrm{i}} \cdot \text { Return }_{i t}+\varepsilon_{i t}
$$

Assuming that firm $i$ and $j$ have identical profit performance, the following formulae are used to forecast their earnings:

$$
\begin{aligned}
& E\left(\text { Earnings }_{i i t}=\alpha_{\mathrm{i}}+\beta_{\mathrm{i}} \cdot \text { Return }_{i t}\right. \\
& E\left(\text { Earnings }_{i j t}=\alpha_{j}+\beta_{j} \cdot \text { Return }_{i t}\right.
\end{aligned}
$$

$E\left(\right.$ Earnings $_{i i t}$, is the expected income of firm $i$ in year $t$, whereas $E(\text { Earnings })_{i j t}$ denotes the projected income of firm $j$ using firm $j$ 's method for recognizing firm $i$ 's profit in year $t$. In both Equations (2) and (3), the return of firm $i$ is employed to guarantee that the same is taken into consideration.

Then, take the average of the absolute difference between the two predicted returns generated by the accounting systems of firm $i$ and $j$. The number is then assigned a negative value, indicating that bigger values of $C O M P A C C T_{i j t}$ indicate more AC between the two firms:

$$
\operatorname{COMPACCT}_{i j t}=-1 / 16 * \sum_{t-15}^{t} \mid E\left(\text { Earnings }_{i i t}\right)-E\left(\text { Earnings }_{i j t}\right) \mid
$$

The averages the COMPACC $T_{i j t}$ values for firms $i$ in year $t$ to provide a comparative measure for that firm in each year. firms.

$\mathrm{COMP} 4_{i t}$ is the average of the four largest COMPACCT values in year $t$ for the four $j$

COMPIND $_{i t}$ is the average of COMPACCT for all firms in the same industry as firm $i$ for the year $t$.

CSR: CSR ECONOMIC; CSR ENVIRONMENT; CSR SOCIAL; the equivalent CSR ALL is the social responsibility disclosure score for economic, environmental, and social actions, with the average value [5].

The following is the calculating formula:

$$
\begin{gathered}
\text { CSR_ECONOMIC } i=\frac{\sum X_{i}}{n_{i}} \\
\text { CSR_ENVIRONMENT }{ }_{i}=\frac{\sum X_{i}}{n_{i}} \\
\text { CSR_SOCIAL } i=\frac{\sum X_{i}}{n_{i}} \\
\text { CSR_ALL } i=\frac{\sum X_{i}}{n_{i}}
\end{gathered}
$$

$X_{i}$ If the company meets criteria i the recorded value is 1 ; if not, the recorded value is 0 .

$n_{i}$ is the expected number of criteria for the firm $i$; the value is in the range $[1 ; 6]$ for economic topics (GRI 200); the value is in the interval [1;8] for environmental topics (GRI $300)$; and values in the range $[1 ; 19]$ for social topics (GRI 400).

\subsection{Control Variable}

The model's control variables are drawn from several prior research [68-70]. SIZE shows the firm's size as defined by the ln of Total Assets [71,72]. Larger organizations are more vulnerable to earnings fluctuation risk than smaller firms [68]. As a result, large enterprises' sustainable income will be lower than the revenue of smaller firms. When 
total debt is divided by total assets, we obtain the debt ratio variable (DEBT), which is utilized as a control variable since enterprises with high debt ratios are more likely to experience financial difficulties, resulting in lower revenue levels. Vichitsarawong and Pornupatham [68] examined debt ratios and discovered a negative correlation between debt and EP. CASH as a percentage of total assets, as measured in cash and cash equivalents. Typically, firms with EP retain a specific proportion of cash on hand, implying a positive association between cash holdings and EP [73]. DIVY stands for dividend yield, which is calculated as the yearly payout divided by the stock's market value [74]. Dividend yield changes in a good manner in response to EP in order to entice investors. AGE denotes the number of years in business as determined by the logarithm of the number of years the firm has been publicly traded $[19,75]$. The longer an organization has been in operation and is publicly traded, the more probable it is that it want EP in order to preserve consumer confidence while also benefiting corporations, investors, shareholders, and stakeholders [75].

$$
\begin{gathered}
\delta_{1}, \delta_{2} \ldots \delta_{6}: \text { coefficient } \\
\varepsilon_{i t}: \text { Random error }
\end{gathered}
$$

\section{Research Results}

\subsection{Descriptive Statistics}

Descriptive statistics for the study variables are presented in Table 1. COMP4 is the average of the greatest comparable values for four businesses $j$ in year $t$ with a mean of -0.006 . COMPIND is the average of COMPACCT for all firms operating in the same industry as company $I$ in year $t$, with a mean of -0.021 and a range of -0.125 to -0.006 for the minimum and highest values. Both COMP4 and COMPIND scores are negative and relatively low, indicating a poor level of comparability in Vietnam. CSR ECONOMIC; CSR ENVIRONMENTAL; CSR SOCIAL; The related CSR ALL variable represents the social responsibility disclosure score for economic, environmental, and social actions [5]. The average value of economic, environmental, and social responsibility activities, as well as the average value of overall CSR activities, are as follows: $0.234 ; 0.295 ; 0.244 ; 0.254$; which is relatively low, indicating that social responsibility disclosure in Vietnam is quite low.

Table 1. Descriptive statistics of variables.

\begin{tabular}{ccccc}
\hline Variables & Mean & Std. Dev. & Min & Max \\
\hline PESISTENCE & 0.247 & 0.396 & -1.602 & 0.941 \\
COMP4 & -0.006 & 0.006 & -0.043 & -0.001 \\
COMPIND & -0.021 & 0.013 & -0.125 & -0.006 \\
CSR_ECONOMIC & 0.234 & 0.121 & 0.000 & 0.833 \\
CSR_ENVIRONMENT & 0.295 & 0.266 & 0.000 & 1.000 \\
CSR_SOCIAL & 0.244 & 0.123 & 0.000 & 0.737 \\
CSR_ALL & 0.254 & 0.131 & 0.000 & 0.727 \\
SIZE & 28.231 & 1.209 & 25.340 & 31.027 \\
CASH & 0.100 & 0.090 & 0.001 & 0.687 \\
DIVY & 0.088 & 0.055 & 0.000 & 0.250 \\
AGE & 2.777 & 0.451 & 1.792 & 3.689 \\
DEBT & 0.516 & 0.191 & 0.040 & 0.862 \\
\hline
\end{tabular}

Source: Author's calculations from research sample.

\subsection{Correlation Matrix}

The correlation matrix in Table 2 demonstrates that comparable variables (COMP4; COMPID), CSR (CSR_ECONOMIC; CSR_ENVIRONMENT; CSR_SOCIAL; CSR_ALL), cash debt ratio (CASH), dividend ratio (DIVY), and years in business (AGE) are positively related to earnings sustainability (PESISTENCE), whereas size (SIZE) and debt ratio (DEBT) are negatively related. The correlation coefficient between the CSR_ALL and CSR_ENVIRONMENT disclosure measures is 0.857 ; the correlation coefficient between the 
CSR_ALL and CSR_SOCIAL disclosure measures is 0.895 , indicating that these variables are closely related and approximately equivalent when used in conjunction to measure CSR. Correlation coefficients between the measured variables COMP4; COMPIND are 0.736, nearly 0.8 , indicating that these two variables are highly correlated and hence adequate for evaluating comparability in the research. Additionally, the findings indicate that the model does not exhibit significant multicollinearity, since no pairwise correlation coefficient has an absolute value larger than 0.9 [76].

\subsection{Main Results}

The study uses regression modeling to investigate the link between CSR and comparability and EP (Table 3), as well as the relationship between the variables. We used the Hansen test in the GMM model to examine the model's overidentification constraints. The p-value for each model 1-4 in the Hansen test is 20.99 percent; 20.36 percent; 13.59 percent; and 16.19 percent, all of which are more than $10 \%$, indicating that the $\mathrm{H} 0$ model is a solid model according to Hansen's test. Columns 1-4 correspond to models (1), (2), (3), and (4), respectively, by measuring the relevant CSR disclosure variable: CSR_ECONOMIC; CSR_ENVIRONMENT; CSR_SOCIAL; and CSR_ALL. According to Hypothesis 1, CSR disclosure has a beneficial influence on revenue sustainability. The results indicate that the correlation coefficients for CSR are positive and statistically significant, implying that Hypothesis 1 is verified. This outcome corroborates previous research findings $[41,47,48,66]$. This is because CSR efforts help businesses manage relationships with their stakeholders more efficiently by allowing them to build, develop, and maintain connections with essential resources. Firms commonly report the quality of earnings as reflected earnings smoothing to create stakeholder connections and protect stakeholder interests [15]. As a result, developing solid relationships with stakeholders may assist a business in operating more efficiently [28], resulting in an increase in EP. Furthermore, stakeholders use the information to make decisions that benefit them [31,32], therefore organizations tend to have good CSR disclosure to enhance their public image and assist them in maintaining a stable market position [33-35]. On the other hand, a firm with good CSR incentives might lead to closer links with customers and suppliers, which could contribute to the establishment of a brand and reputation for high-quality products and services [36,37]. Furthermore, being aware of social and environmental changes may assist firms in improving performance, reducing income management risks, and maintaining the stability of high-quality financial statements while growing EP [16]. According to McWilliams, Siegel [40], businesses under societal and political pressure establish their legitimacy by doing acts that benefit society and improve the environment in which they operate. As a result, implementing CSR is the company's best option for gaining a social reputation [41]. Furthermore, because organizations always operate inside particular cultures, institutions, and laws [39], managers are constantly attempting to strengthen their companies' legitimacy in order to fulfill the promises made to stakeholders, resulting in lower investment risks. In other words, legitimacy is a key and minimum necessary component of a company's reputation, and hence a valuable intangible asset $[43,44]$. Many advantages may be realized if businesses go above and beyond the legal minimum, such as more qualified employees and loyal customers $[45,46]$. As a result, permitted activities such as CSR were implemented to assist the company in enhancing its EP $[41,47,48]$. 
Table 2. Pearson's correlation coefficient matrix.

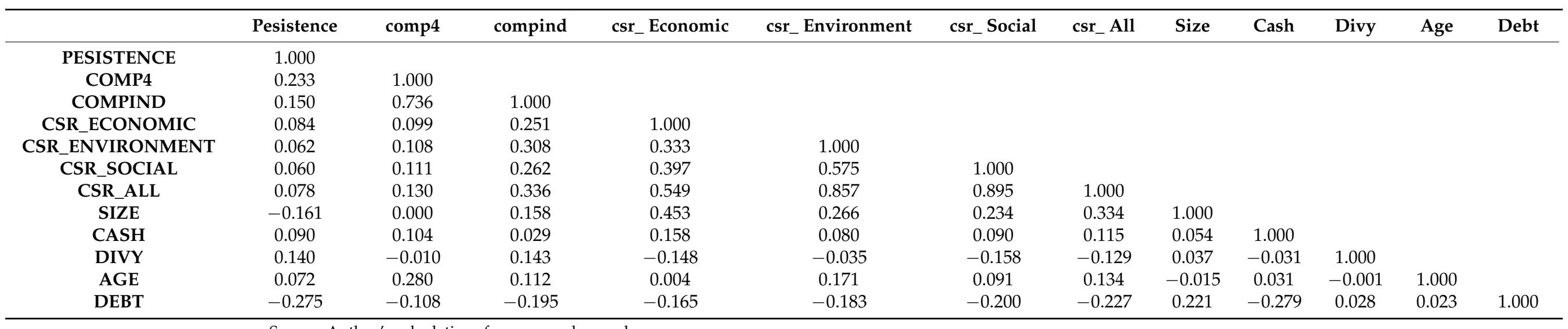

Source: Author's calculations from research sample. 
Table 3. Regression result about the relationship between CSR, AC and EP.

\begin{tabular}{|c|c|c|c|c|}
\hline Variables & Model 1 & Model 2 & Model 3 & Model 4 \\
\hline COMP4 & $\begin{array}{c}7.779 * * \\
{[2.18]}\end{array}$ & $\begin{array}{c}8.393^{* * *} \\
{[2.66]}\end{array}$ & $\begin{array}{c}7.052 * * \\
{[2.17]}\end{array}$ & $\begin{array}{c}7.382 * * * \\
{[2.95]}\end{array}$ \\
\hline CSR_ECONOMIC & $\begin{array}{c}0.550 * * * \\
{[5.78]}\end{array}$ & & & \\
\hline CSR_ENVIRONMENT & & $\begin{array}{c}0.176^{* * *} \\
{[2.99]}\end{array}$ & & \\
\hline CSR_SOCIAL & & & $\begin{array}{c}0.244 * \\
{[1.80]}\end{array}$ & \\
\hline CSR_ALL & & & & $\begin{array}{c}0.412 * * * \\
{[3.41]}\end{array}$ \\
\hline SIZE & $\begin{array}{c}-0.088^{* * *} \\
{[-12.71]}\end{array}$ & $\begin{array}{c}-0.063 * * * \\
{[-4.89]}\end{array}$ & $\begin{array}{c}-0.059 * * * \\
{[-4.49]}\end{array}$ & $\begin{array}{c}-0.072 * * * \\
{[-5.89]}\end{array}$ \\
\hline CASH & $\begin{array}{c}0.470 * * * \\
{[7.28]}\end{array}$ & $\begin{array}{c}0.500 * * * \\
{[3.39]}\end{array}$ & $\begin{array}{c}0.464^{* * *} \\
{[3.96]}\end{array}$ & $\begin{array}{c}0.540 * * * \\
{[3.84]}\end{array}$ \\
\hline DIVY & $\begin{array}{c}1.349 * * * \\
{[5.20]}\end{array}$ & $\begin{array}{c}1.267^{* * * *} \\
{[4.14]}\end{array}$ & $\begin{array}{c}1.367^{* * * *} \\
{[4.71]}\end{array}$ & $\begin{array}{c}1.529 * * * \\
{[5.49]}\end{array}$ \\
\hline AGE & $\begin{array}{c}0.086^{* * *} \\
{[3.15]}\end{array}$ & $\begin{array}{l}0.048 \\
{[1.39]}\end{array}$ & $\begin{array}{c}0.078 * * \\
{[2.45]}\end{array}$ & $\begin{array}{c}0.057^{*} \\
{[1.75]}\end{array}$ \\
\hline DEBT & $\begin{array}{c}-0.405^{* * *} \\
{[-6.06]}\end{array}$ & $\begin{array}{c}-0.508^{* * *} \\
{[-7.92]}\end{array}$ & $\begin{array}{c}-0.496^{* * *} \\
{[-7.75]}\end{array}$ & $\begin{array}{c}-0.471^{* * *} \\
{[-7.83]}\end{array}$ \\
\hline CONS & $\begin{array}{c}2.445^{* * *} \\
{[12.59]}\end{array}$ & $\begin{array}{c}2.002 * * * \\
{[5.68]}\end{array}$ & $\begin{array}{c}1.779 * * * \\
{[5.42]}\end{array}$ & $\begin{array}{c}2.098^{* * *} \\
{[6.61]}\end{array}$ \\
\hline Hansen test & 0.2099 & 0.2036 & 0.1359 & 0.1679 \\
\hline R squared & 0.224 & 0.219 & 0.208 & 0.222 \\
\hline
\end{tabular}

*,**,*** denote the level of significance of 10,5 and $1 \%$, respectively; t-statistics in brackets.

In particular, in the Vietnamese context, CSR disclosure is just voluntary, not mandatory, but it is encouraged by the Government to enhance the effectiveness and transparency of the market. If companies have a suitable strategy in CSR implementation, the financial performance will be improved and positively directly impact EP [77,78]. Understanding CSR's role in companies' operational process, the Vietnamese government promulgated several legal documents to regulate the degree of CSR disclosure in Vietnam. The most recent is Circular 155/2015/TT-BTC about the instruction for disclosing information of Vietnamese listed firms. Since this circular has come into force, the magnitude of information disclosure is higher and has resulted in enhancing companies' EP. However, after 2018, no new regulations on CSR disclosure were issued, so this study's result about the pivotal role of CSR on EP would motivate future research to explore more about this topic in order to provide a more comprehensive view for other related parties.

According to Hypothesis 2, comparability has a beneficial influence on income sustainability. As a consequence of the results, the correlation coefficient of comp 4 for the four models 1-4 corresponding to various CSR metrics is as follows 7.779; 8.393; 7.052; 7.382 are all positive and statistically significant at $p<0.01$. This results corroborates previous research findings $[60,61]$. Accounting information is critical for shareholders and stakeholders because they can only use, analyze, and compare the accounting information included in financial statements if the companies' accounting systems are comparable, which can be defined as the degree of similarity between firms' accounting systems [50]. As a result, the increase in AC of the companies would lead to enhancing EP because by having that, investors can assess and compare the financial information between companies. Our results are in line with the signal theory that when enterprises earn a high profit, grow their revenue, and maintain a positive image, they send a signal to investors, organizations, and users who wish to utilize financial data to make sound decisions [54]. Consequently, firms with solid financial backgrounds try to improve their AC to help investors accurately assess companies' financial status and attract investment from shareholders. This results in the growth of enterprises' EP. Financial statements of companies within a country or region, 
on the other hand, must adhere to a standard accounting policy regime that guarantees that the information in the financial statements is clearly understandable by consumers while also ensuring comparability. The benefits of comparability on the financial statement were spotted our such as enhanced analyst follow-up [50], less credit risk [55], and a higher degree of mergers and acquisitions in foreign-owned firms [56]. Discretionary accruals are positively connected with future performance when there is insufficient governance, which they interpret as evidence that discretionary accruals meet future performance expectations [57,58]. Managers can update their preliminary data and alter their operations based on new information collected from their colleagues' financial records. According to previous research, comparability reduces the cost of data collection and processing, hence increasing the amount and quality of data or, in other words, enhancing EP [50,55,56,59,79]. AC expands the pool of knowledge available to managers, making data aggregation easier and reducing judgment uncertainty. Assume that managers have a better grasp of the industry and its general environment. In such situations, they may compare a company's performance to others and understand as well as foresee economic trends and their impact on the firm. As a result, providing higher-quality accruals to aid in the maintenance of profitability or the enhancement of EP $[59,60,62]$.

Our findings suit the Vietnamese context. Our sample includes just 76 companies, but such firms are key players of the Vietnamese stock market and accounted for nearly $50 \%$ of market capitalization. As a result, they always try to improve the AC to better interpret their competitive advantage with other rivals in the same business sector. In addition, these companies are usually global firms; in this case, they would prefer to adopt IFRS in order to improve the AC ability and compete with other enterprises worldwide. So, the EP would be enhanced through adopting IFRS or, in other words, an increase in AC helps to improve EP $[8,80,81]$.

\subsection{Robustness Test}

To strengthen the confidence of the research findings, we employ a distinct representation of financial statement comparability and evaluate CSR across measurement components. Specifically, COMPIND is used to assess comparability, and CSR is quantified using four factors: CSR ECONOMIC; CSR ENVIRONMENTAL; CSR SOCIAL; and CSR. All relate to models (5), (6), and (7), respectively (8). The research findings indicate that both hypothesis $\mathrm{H} 1$ and $\mathrm{H} 2$ are validated by positive correlation coefficients and that all three are statistically significant (Table 4). Whether COMP4 or COMPIND is used to determine comparability, both produce study findings demonstrating that comparability has a beneficial influence on income sustainability. The findings of this study corroborate those found in the prior research of Chen and Gong [59], Aier, Comprix [60], Demerjian, Lev [62].

Table 4. Regression result about the relationship between CSR, AC, and EP with other indicators.

\begin{tabular}{|c|c|c|c|c|}
\hline Variables & Model 5 & Model 6 & Model 7 & Model 8 \\
\hline COMPIND & $\begin{array}{c}12.336^{* * *} \\
{[3.23]}\end{array}$ & $\begin{array}{c}16.263^{* * *} \\
{[6.09]}\end{array}$ & $\begin{array}{l}1.779 * \\
{[1.87]}\end{array}$ & $\begin{array}{c}13.638^{* * *} \\
{[4.81]}\end{array}$ \\
\hline CSR_ECONOMIC & $\begin{array}{c}0.320 * * \\
{[2.43]}\end{array}$ & & & \\
\hline CSR_ENVIRONMENT & & $\begin{array}{c}0.280 * * * \\
{[4.96]}\end{array}$ & & \\
\hline CSR_SOCIAL & & & $\begin{array}{l}0.216^{*} \\
{[1.68]}\end{array}$ & \\
\hline CSR_ALL & & & & $\begin{array}{c}0.482^{* * *} \\
{[5.90]}\end{array}$ \\
\hline SIZE & $\begin{array}{c}-0.113^{* * *} \\
{[-5.39]}\end{array}$ & $\begin{array}{c}-0.090^{* * *} \\
{[-4.63]}\end{array}$ & $\begin{array}{c}-0.072 * * * \\
{[-6.42]}\end{array}$ & $\begin{array}{c}-0.107^{* * *} \\
{[-5.38]}\end{array}$ \\
\hline CASH & $\begin{array}{l}0.362 \\
{[1.05]}\end{array}$ & $\begin{array}{l}0.229 \\
{[0.75]}\end{array}$ & $\begin{array}{c}0.497 * * * \\
{[4.86]}\end{array}$ & $\begin{array}{l}0.214 \\
{[0.79]}\end{array}$ \\
\hline
\end{tabular}


Table 4. Cont.

\begin{tabular}{ccccc}
\hline Variables & Model 5 & Model 6 & Model 7 & Model 8 \\
\hline DIVY & $1.302 * * *$ & $1.130^{* * *}$ & $1.132^{* * *}$ & $1.401^{* * *}$ \\
& {$[2.81]$} & {$[3.68]$} & {$[4.50]$} & {$[5.46]$} \\
AGE & $0.303^{* * *}$ & $0.278^{* * *}$ & $0.109^{* * *}$ & $0.291^{* * *}$ \\
& {$[10.22]$} & {$[7.87]$} & {$[4.14]$} & {$[13.85]$} \\
DEBT & $-0.520 * * *$ & $-0.371^{* * *}$ & $-0.500^{* * *}$ & $-0.469 * * *$ \\
CONS & {$[-5.51]$} & {$[-4.46]$} & {$[-7.83]$} & {$[-6.80]$} \\
& $2.766^{* * *}$ & $2.169 * * *$ & $2.071^{* * *}$ & $2.548^{* * *}$ \\
Hansen test & {$[4.68]$} & {$[3.93]$} & {$[7.30]$} & {$[4.57]$} \\
R squared & 0.2147 & 0.4252 & 0.186 & 0.3502 \\
F $^{* * * * * *}$ denote the level of significance of 10,5 and 1\%, respectively; t-statistics in brackets. & 0.385
\end{tabular}

\section{Conclusions}

The study's purpose is to examine the effect of CSR disclosure and comparability on the EP of publicly traded non-financial firms in Vietnam. We employ the GMM regression approach to account for endogenous phenomena using a sample size of 76 businesses from 2014 to 2017. The findings demonstrate that CSR disclosure and comparability increase EP. This demonstrates the importance of socially responsible information disclosure in promoting information transparency and, consequently, company EP. Additionally, comparability is a good channel for investor decision-making and aids in the smoothing of results. We test the robustness of the research model using an alternative method of assessing the independent variables. In summary, the study findings support the signal theory's explanation for the link between research themes.

Our findings provide several theoretical implications for the existing literature about CSR disclosure, AC, and EP. First of all, this is the first study that explored the link between CSR-AC, and EP in the Vietnamese context. Besides, our study also applies the signaling theory to explain the association above. Finally, the existing literature about EP and AC is rare, and the findings are still inconsistent, so the study contributes to a deeper insight into the given topics. The study has policy implications for strengthening the regulatory framework governing CSR for publicly traded firms in order to promote information transparency and provide investors with more information to make informed investment decisions. As a result, the management agency should continue to release additional guidance circulars in accordance with worldwide CSR disclosure rules. Maintaining a business image is critical for managers in all circumstances, and improving non-financial information will assist in boosting stakeholder trust.

Due to the study's limited sample size, it is possible that it may not adequately cover the Vietnamese market. As a result, future research must include a larger sample size. Additionally, studying the financial sector in terms of operational and commercial characteristics will contribute to a broader understanding of the research topic.

Author Contributions: Conceptualizaiotion, N.V.K.; formal analysis, N.V.K., N.T.L., L.H.T.A., C.T.M.T. and H.T.N.L.; writing - review and editing, N.V.K., N.T.L., L.H.T.A., C.T.M.T., H.T.N.L., A.A.A.R., A.M. All authors have read and agreed to the published version of the manuscript.

Funding: This research is funded by the University of Economics and Law, Vietnam National University, Ho Chi Minh City, Vietnam.

Institutional Review Board Statement: Not applicable.

Informed Consent Statement: Informed consent was obtained for secondary data via Eikon Refinitiv.

Data Availability Statement: The data will be made available upon request.

Conflicts of Interest: The authors declare no conflict of interest. 


\section{References}

1. Crane, A.; Matten, D. Corporate social responsibility as a field of scholarship. In Corporate Social Responsibility, Volumes I, II E III, Andrew Crane, Dirk Matten; Sage: London, UK, 2007. Available online: https:/ / ssrn.com/abstract=1865404 (accessed on 11 December 2021).

2. Carroll, A.B. The pyramid of corporate social responsibility: Toward the moral management of organizational stakeholders. Bus. Horiz. 1991, 34, 39-48. [CrossRef]

3. Freeman, R.E. Strategic Management: A Stakeholder Approach; Pitman Press: Boston, MA, USA, 1984.

4. Guthrie, J.; Mathews, M.R. Corporate social accounting in Australasia. In Research in Corporate Social Performance and Policy; JAI Press: New York, NY, USA, 1985; pp. 251-277.

5. GRI. Full Set of GRI Standards 2021. Available online: https://www.globalreporting.org/how-to-use-the-gri-standards/gristandards-english-language/ (accessed on 11 December 2021).

6. Vogel, D.J. Is There a Market for Virtue?: The Business Case for Corporate Social Responsibility. Calif. Manag. Rev. 2005, 47, 19-45.

7. Du, S.; Bhattacharya, C.; Sen, S. Maximizing Business Returns to Corporate Social Responsibility (CSR): The Role of CSR Communication. Int. J. Manag. Rev. 2010, 12, 8-19. [CrossRef]

8. Wijayana, S.; Gray, S.J. Institutional Factors and Earnings Management in the Asia-Pacific: Is IFRS Adoption Making a Difference? Manag. Int. Rev. 2019, 59, 307-334. [CrossRef]

9. Lund-Thomsen, P.; Lindgreen, A.; Vanhamme, J. Industrial Clusters and Corporate Social Responsibility in Developing Countries: What We Know, What We do not Know, and What We Need to Know. J. Bus. Ethics 2016, 133, 9-24. [CrossRef]

10. Puppim de Oliveira, J.A.; Jabbour, C.J.C. Environmental Management, Climate Change, CSR, and Governance in Clusters of Small Firms in Developing Countries. Bus. Soc. 2016, 56, 130-151. [CrossRef]

11. Griesse, M.A. The Geographic, Political, and Economic Context for Corporate Social Responsibility in Brazil. J. Bus. Ethics 2007, 73, 21-37. [CrossRef]

12. Yang, W.; Hyndman, D.W.; Winkler, J.A.; Viña, A.; Deines, J.M.; Lupi, F.; Luo, L.; Li, Y.; Basso, B.; Zheng, C.; et al. Urban water sustainability: Framework and application. Ecol. Soc. 2016, 21, 4. [CrossRef]

13. Xiao, J.Z.; Gao, S.S.; Heravi, S.; Cheung, Y.C. The Impact of Social and Economic Development on Corporate Social and Environmental Disclosure in Hong Kong and the U.K. Adv. Int. Account. 2005, 18, 219-243. [CrossRef]

14. Matten, D.; Moon, J. Corporate Social Responsibility. J. Bus. Ethics 2004, 54, 323-337. [CrossRef]

15. Nurdin, E.; Hamzah, D. Empirical Testing of Corporate Social Responsibility Disclosure as a Mechanism to Improve the Earnings Persistence and Stock Return in Indonesia. Spec. J. Account. Econ. 2016, 2, 40-47.

16. Rezaee, Z.; Dou, H.; Zhang, H. Corporate social responsibility and earnings quality: Evidence from China. Glob. Finance J. 2020, 45, 100473. [CrossRef]

17. Nguyen, M.; Bensemann, J.; Kelly, S. Corporate social responsibility (CSR) in Vietnam: A conceptual framework. Int. J. Corp. Soc. Responsib. 2018, 3, 9. [CrossRef]

18. Hoang, T.C.; Abeysekera, I.; Ma, S. Earnings Quality and Corporate Social Disclosure: The Moderating Role of State and Foreign Ownership in Vietnamese Listed Firms. Emerg. Mark. Finance Trade 2019, 55, 272-288. [CrossRef]

19. Vo, H.T.M.; Arato, M. Corporate social responsibility in a developing country context: A multi-dimensional analysis of modern food retail sector in Vietnam. Agroecol. Sustain. Food Syst. 2020, 44, 284-309. [CrossRef]

20. Thuy, C.T.M.; Khuong, N.V.; Canh, N.T.; Liem, N.T. Corporate Social Responsibility Disclosure and Financial Performance: The Mediating Role of Financial Statement Comparability. Sustainability 2021, 13, 10077. [CrossRef]

21. Wood, D.J.; Jones, R.E. Stakeholder Mismatching: A Theoretical Problem in Empirical Research on Corporate Social Performance; University of Toronto Press: Toronto, ON, Canada, 2016; pp. 315-363.

22. Roberts, R.W. Determinants of corporate social responsibility disclosure: An application of stakeholder theory. Account. Organ. Soc. 1992, 17, 595-612. [CrossRef]

23. Gelb, D.S.; Strawser, J.A. Corporate Social Responsibility and Financial Disclosures: An Alternative Explanation for Increased Disclosure. J. Bus. Ethics 2001, 33, 1-13. [CrossRef]

24. Vitolla, F.; Raimo, N.; Rubino, M.; Garzoni, A. The impact of national culture on integrated reporting quality. A stakeholder theory approach. Bus. Strat. Environ. 2019, 28, 1558-1571. [CrossRef]

25. Chiu, T.-K.; Wang, Y.-H. Determinants of Social Disclosure Quality in Taiwan: An Application of Stakeholder Theory. J. Bus. Ethics 2015, 129, 379-398. [CrossRef]

26. Cornell, B.; Shapiro, A.C. Corporate Stakeholders and Corporate Finance. Financ. Manag. 1987, 16, 5-14. [CrossRef]

27. Barnett, M.L.; Salomon, R.M. Beyond dichotomy: The curvilinear relationship between social responsibility and financial performance. Strat. Manag. J. 2006, 27, 1101-1122. [CrossRef]

28. Cordeiro, J.J.; Tewari, M. Firm Characteristics, Industry Context, and Investor Reactions to Environmental CSR: A Stakeholder Theory Approach. J. Bus. Ethics 2015, 130, 833-849. [CrossRef]

29. Vitolla, F.; Raimo, N.; Rubino, M.; Garzoni, A. How pressure from stakeholders affects integrated reporting quality. Corp. Soc. Responsib. Environ. Manag. 2019, 26, 1591-1606. [CrossRef]

30. Yu, H.-C.; Kuo, L.; Kao, M.-F. The relationship between CSR disclosure and competitive advantage. Sustain. Account. Manag. Policy J. 2017, 8, 547-570. [CrossRef]

31. Grinblatt, M.; Hwang, C.Y. Signalling and the Pricing of New Issues. J. Finance 1989, 44, 393-420. [CrossRef] 
32. Rezaee, Z. Business sustainability research: A theoretical and integrated perspective. J. Account. Lit. 2016, 36, 48-64. [CrossRef]

33. Huang, X.; Watson, L. Corporate social responsibility research in accounting. J. Account. Lit. 2015, 34, 1-16. [CrossRef]

34. Lys, T.; Naughton, J.P.; Wang, C. Signaling through corporate accountability reporting. J. Account. Econ. 2015, 60, 56-72. [CrossRef]

35. Hummel, K.; Schlick, C. The relationship between sustainability performance and sustainability disclosure-Reconciling voluntary disclosure theory and legitimacy theory. J. Account. Public Policy 2016, 35, 455-476. [CrossRef]

36. Orlitzky, M.; Schmidt, F.L.; Rynes, S.L. Corporate Social and Financial Performance: A Meta-Analysis. Organ. Stud. 2003, 24, 403-441. [CrossRef]

37. Peloza, J. The Challenge of Measuring Financial Impacts From Investments in Corporate Social Performance. J. Manag. 2009, 35, 1518-1541. [CrossRef]

38. Wang, F.; Zhang, Z.; Xu, L. Corporate social responsibility and financial statement comparability: Evidence from China. Corp. Soc. Responsib. Environ. Manag. 2020, 27, 1375-1394. [CrossRef]

39. Suchman, M.C. Managing Legitimacy: Strategic and Institutional Approaches. Acad. Manag. Rev. 1995, 20, 571-610. [CrossRef]

40. McWilliams, A.; Siegel, D.S.; Wright, P.M. Corporate Social Responsibility: Strategic Implications*. J. Manag. Stud. 2006, 43, 1-18. [CrossRef]

41. Rupley, K.H.; Brown, D.; Marshall, R.S. Governance, media and the quality of environmental disclosure. J. Account. Public Policy 2012, 31, 610-640. [CrossRef]

42. Bansal, P.; Roth, K. Why Companies Go Green: A Model of Ecological Responsiveness. Acad. Manag. J. 2000, 43, 717-736.

43. Hall, S. Culture, community, nation. Cult. Stud. 1993, 7, 349-363. [CrossRef]

44. Chiu, S.-C.; Sharfman, M. Legitimacy, Visibility, and the Antecedents of Corporate Social Performance: An Investigation of the Instrumental Perspective. J. Manag. 2009, 37, 1558-1585. [CrossRef]

45. Fombrun, C.J.; Gardberg, N. Who's Tops in Corporate Reputation? Corp. Reput. Rev. 2000, 3, 13-17. [CrossRef]

46. Brammer, S.J.; Pavelin, S. Corporate Reputation and Social Performance: The Importance of Fit. J. Manag. Stud. 2006, 43, 435-455. [CrossRef]

47. Haniffa, R.M.; Cooke, T.E. The impact of culture and governance on corporate social reporting. J. Account. Public Policy 2005, 24, 391-430. [CrossRef]

48. Magness, V. Strategic posture, financial performance and environmental disclosure. Account. Audit. Account. J. 2006, 19, 540-563. [CrossRef]

49. Raimo, N.; Vitolla, F.; Nicolò, G.; Polcini, P.T. CSR disclosure as a legitimation strategy: Evidence from the football industry. Meas. Bus. Excel. 2021, 25, 493-508. [CrossRef]

50. De Franco, G.; Kothari, S.P.; Verdi, R.S. The Benefits of Financial Statement Comparability. J. Account. Res. 2011, 49, 895-931. [CrossRef]

51. Financial Accounting Standards Board (FASB). Concepts Statements. 1980. Available online: https://www.fasb.org/jsp/FASB/ Page/PreCodSectionPage\&cid=1176156317989 (accessed on 17 January 2022).

52. Srivastava, A. Why have measures of earnings quality changed over time? J. Account. Econ. 2014, 57, 196-217. [CrossRef]

53. Schipper, K. Earnings management. Account. Horiz. 1989, 3, 91-102.

54. Verrecchia, R.E. Discretionary disclosure. J. Account. Econ. 1983, 5, 179-194. [CrossRef]

55. Kim, S.; Kraft, P.; Ryan, S.G. Financial statement comparability and credit risk. Rev. Account. Stud. 2013, 18, 783-823. [CrossRef]

56. Francis, J.R.; Huang, S.; Khurana, I.K. The Role of Similar Accounting Standards in Cross-Border Mergers and Acquisitions. Contemp. Account. Res. 2016, 33, 1298-1330. [CrossRef]

57. Bowen, R.M.; Rajgopal, S.; Venkatachalam, M. Accounting Discretion, Corporate Governance, and Firm Performance. Contemp . Account. Res. 2008, 25, 351-405. [CrossRef]

58. Davoodi, S. Relationship between accounting comparability and accrual-based and real earnings management. J. Knowl. Account. 2019, 10, 91-113.

59. Chen, A.; Gong, J.J. Accounting comparability, financial reporting quality, and the pricing of accruals. Adv. Account. 2019, 45, 100415. [CrossRef]

60. Aier, J.K.; Comprix, J.; Gunlock, M.T.; Lee, D. The Financial Expertise of CFOs and Accounting Restatements. Account. Horiz. 2005, 19, 123-135. [CrossRef]

61. Delvira, M.; Nelvirita, N. Pengaruh Risiko Sistematik, Leverage Dan Persistensi Laba Terhadap Earnings Response Coefficient (ERC). Wahana Ris. Akunt. 2013, 1, 129-154.

62. Demerjian, P.R.; Lev, B.; Lewiswestern, M.F.; McVay, S.E. Managerial Ability and Earnings Quality. Account. Rev. 2012, 88, 463-498. [CrossRef]

63. Arellano, M.; Bover, O. Another look at the instrumental variable estimation of error-components models. J. Econ. 1995, 68, 29-51. [CrossRef]

64. Arellano, M. Sargan's Intrumental Variables Estimation and the Generalized Method of Moments. J. Bus. Econ. Stat. 2002, 20, 450-459. [CrossRef]

65. Hansen, L.P. Large Sample Properties of Generalized Method of Moments Estimators. Econometrica 1982, 50, 1029. [CrossRef]

66. Lassaad, B.M.; Khamoussi, H. Determinants of communication about corporate social responsibility: Case of French companies. Int. J. Contemp. Bus. Stud. 2012, 3, 49-60. 
67. Ranasinghe, D.; Mather, P.; Young, S. Board structure and earnings persistence: The mediation effect of board processes. Aust. J. Manag. 2019, 45, 266-293. [CrossRef]

68. Vichitsarawong, T.; Pornupatham, S. Do audit opinions reflect earnings persistence? Manag. Audit. J. 2015, 30, 244-276. [CrossRef]

69. Fortin, S.; Pittman, J.A. The Role of Auditor Choice in Debt Pricing in Private Firms. Contemp. Account. Res. 2007, 24, 859-896. [CrossRef]

70. Paulo, I.I.S.L.d.; Cavalcante, P.R.N.; Paulo, E. The Relationship Between Auditing Quality and Accounting Conservatism in Brazilian Companies. Rev. Educ. Pesqui. Contab. 2013, 7, 293-314.

71. Hutton, A.P.; Marcus, A.J.; Tehranian, H. Opaque financial reports, R2, and crash risk. J. Financ. Econ. 2009, 94, 67-86. [CrossRef]

72. Kim, J.-B.; Zhang, L. Financial Reporting Opacity and Expected Crash Risk: Evidence from Implied Volatility Smirks. Contemp. Account. Res. 2014, 31, 851-875. [CrossRef]

73. Chen, N.X.; Chiu, P.-C.; Shevlin, T.J. The Persistence and Pricing of Changes in Multinational Firms' Foreign Cash Holdings. SSRN 2019. [CrossRef]

74. Persakis, A.; Iatridis, G.E. Earnings quality under financial crisis: A global empirical investigation. J. Multinatl. Financ. Manag. 2015, 30, 1-35. [CrossRef]

75. Cui, J.; Jo, H.; Na, H. Does Corporate Social Responsibility Affect Information Asymmetry? J. Bus. Ethics 2018, 148, 549-572. [CrossRef]

76. Tabachnick, B.G.; Fidell, L.S.; Ullman, J.B. Using Multivariate Statistics; Pearson: Boston, MA, USA, 2007; Volume 5, pp. 481-498.

77. Nguyen, B.T.N.; Tran, H.T.T.; Le, O.H.; Nguyen, P.T.; Trinh, H.-T.; Le, V. Association between Corporate Social Responsibility Disclosures and Firm Value-Empirical Evidence from Vietnam. Int. J. Account. Financ. Rep. 2015, 1, 212. [CrossRef]

78. Ha, H.T.V.; Van, V.T.T.; Hung, D.N. Impact of social responsibility information disclosure on the financial performance of enterprises in Vietnam. Indian J. Finance 2019, 13, 20-36.

79. Chen, C.J.; Ding, Y.; Xu, B. Convergence of accounting standards and foreign direct investment. Int. J. Account. 2014, 49, 53-86. [CrossRef]

80. Gassen, J.; Sellhorn, T. Applying IFRS in Germany: Determinants and Consequences. Betr. Forsch. Prax. 2006, 58, 365-386. [CrossRef]

81. Atwood, T.; Drake, M.S.; Myers, J.N.; Myers, L.A. Do earnings reported under IFRS tell us more about future earnings and cash flows? J. Account. Public Policy 2011, 30, 103-121. [CrossRef] 